DOI: http://dx.doi.org/10.33846/hn41005

http://heanoti.com/index.php/hn

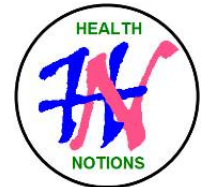

RESEARCH ARTICLE

URL of this article: http://heanoti.com/index.php/hn/article/view/hn41005

\title{
Comparation Between Station Management and Water Source on the Quality of Refill
} Drinking Water in Surabaya

\author{
Nida'an Khafiya ${ }^{1}$, Linda Dewanti ${ }^{2(C A)}$, Wiwin Retnowati ${ }^{3}$ \\ ${ }^{1}$ Student, Faculty of Medicine, Universitas Airlangga, Indonesia; khafiya15@gmail.com \\ ${ }^{2(\mathrm{CA})}$ Departement of Public Health - Preventive Medicine, Faculty of Medicine, Universitas Airlangga, \\ Indonesia; lindaperisdiono@gmail.com \\ ${ }^{3}$ Departement of Microbiology, Faculty of Medicine, Universitas Airlangga, Indonesia; \\ wiwinretnowati@gmail.com
}

\begin{abstract}
Drinking water is both a basic human need and a strong determinant of health. In Indonesia, there are drinking water refill stations (DWRS) which conveniently offer refill drinking water at affordable price. This study aims to determine whether station management amd raw water source influence the quality of drinking water. This cross-sectional study used primary data from questionnaires filled by DWRS owners and secondary data about the quality of refill drinking water from the Surabaya City Health Department. Data was then analyzed by using Chi-Square and Mann-Whitney tests. From 33 registered DWRSs, only 18 stations fulfilled all quality standards of drinking water. Some DWRSs failed to pass microbiological $(n=13)$ and chemical $(\mathrm{n}=2)$ standards. All DWRS passed the physical standard. There was no significant difference found in duration of operation $($ pmicro $=0.956$, pchemical $=0.382$ ), production capacity $($ pmicro $=0.384$; pchemical $=0.495$ ). There was no significant difference found in terms of station management and raw water sources on the quality of refill drinking water.
\end{abstract}

Keywords: drinking water refill station (DWRS); duration of operation; production capacity; raw water source

\section{INTRODUCTION}

Drinking water is water that goes through treatment or without treatment that meets health requirements and can be consumed immediately. To be considered safe, drinking water must meet physical, chemical, microbiological and radioactive parameter requirements ${ }^{(1)}$. Improperly treated drinking water is a source of an array of pathogenic microbes that causes various water-borne diseases, for example, Escherichia coli, Giardia lamblia, Leptospira, and Shigella $s p .^{(2,3)}$ Poor water quality is deemed responsible for around 1.7 million deaths annually ${ }^{(3)}$. Semba, et al in 2009 found that consumption of inexpensive refilled drinking water was found to increase the risk of stunting in children aged 0-59 months by $32 \%$ (95\% CI: $1.20-1.45)^{(4)}$. The physical appearances of water can be one of the considerations in choosing drinking water. Safe drinking water is generally clear, odorless and tasteless ${ }^{(5,6)}$.

Nowadays in Indonesia, refill drinking water sold at drinking water refill stations or DWRS (Indonesian: Depot Air Minum Isi Ulang or DAMIU) is more popular than the tap water provided by Regional Water Supply Company (Indonesian: Perusahaan Daerah Air Minum, PDAM) for daily drinking water needs. This is caused by several factors, such as convenience and relatively cheap prices $^{(7)}$. In maintaining the quality of refill drinking water, the local government through its Health Department has routinely surveilled on DWRSs in Surabaya, East Java, Indonesia. Every 3 months, the water samples from DWRSs are taken and examined to see if it satisfies microbiological, chemical, and physical safety parameters ${ }^{(8,9)}$. From the data provided by the Surabaya City Health Department, we found that only 18 stations fulfilled all quality standards of drinking water and these DWRS still operational. The impact of unhygienic on refill drinking water containing Escherichia coli can cause diarrhea, from Health profile of Surabaya $2016^{(8)}$ we found that the Diarrhea Morbidity Rate $27 \%$. This study aims to know whether the quality of refill drinking water is related to other factors, such as station management and raw water sources ${ }^{(10)}$.

\section{METHODS}

This research was an cross-sectional study. The study was completed in August 2018 to June 2019 in Surabaya, East Java, Indonesia. The data source was both primary and secondary. Primary data were obtained by distributing questionnaires to DWRS staff. It comprised of questions about station management (duration since station's establishment, number of offices, type of business ownership, production capacity, and certification), and raw water sources. Secondary data regarding the quality assessment of refill drinking water was obtained from the Surabaya City Health Department 
database. The quality was assessed by using microbiological, chemical parameters listed in The Ministry of Health's regulation (Permenkes No. 492/Menkes/Per/IV/2010) ${ }^{(1)}$ about the requirement of drinking water.

From the list of registered DWRSs located in Surabaya city, samples were chosen by using a simple random sampling method. The DWRSs with consent and complete data were included in the analysis. The DWRSs which were not operational at the time of the study were excluded. Data was then analyzed by using Chi-Square and Mann-Whitney tests.

\section{RESULTS}

\section{Station Management and Water source}

There were 33 registered DWRSs included in the analysis. Station management include duration since station's establishment, number of offices, type of business ownership, production capacity, and certification. The stations have been operating for $80.4 \pm 47.4$ months with the newest one established in 10 months and the oldest 228 months (19 years). On average, the stations produced 7,775.8 $\pm 1859,4$ liters of drinking water. All stations were personally owned and had no branch office. No stations had been certified ISO 9001. All DWRSs used surface water as their source, with the majority of stations used water source that was located in Prigen.

Table 1. Water source of refill drinking water

\section{Quality of refill drinking water}

\begin{tabular}{ccc}
\hline Water Source & f & $\%$ \\
\hline Prigen & 21 & 63.7 \\
Pandaan & 10 & 30.3 \\
Pacet & 2 & 6 \\
\hline
\end{tabular}

Data about the quality of refill drinking water was obtained from the local Health Department. Out of 33 samples, only 18 stations fulfilled all the criteria mandated by Permenkes 492/Menkes/Per/IV/2010 (Table 2). center, title position: top.

Table 2. Quality of refill drinking water

\begin{tabular}{|c|c|c|c|c|c|c|}
\hline \multirow{2}{*}{$\begin{array}{l}\text { Sample } \\
\text { code }\end{array}$} & \multicolumn{3}{|c|}{ Microbiological standard } & \multicolumn{2}{|c|}{ Chemical standard } & \multirow{2}{*}{$\begin{array}{l}\text { Physical standard } \\
\text { (Pass / Fail) }\end{array}$} \\
\hline & Colifrom & E.Coli & Pass / Fail & Chemical content & Pass / Fail & \\
\hline A1 & $\geq 1$ & $\geq 1$ & $\mathrm{~F}$ & 0 & $\mathrm{P}$ & $\mathrm{P}$ \\
\hline A2 & $\overline{0}$ & $\overline{0}$ & $\mathrm{P}$ & + & $\mathrm{F}$ & $\mathrm{P}$ \\
\hline A3 & 0 & 0 & $\mathrm{P}$ & 0 & $\mathrm{P}$ & $\mathrm{P}$ \\
\hline A4 & 0 & 0 & $\mathrm{P}$ & 0 & $\mathrm{P}$ & $\mathrm{P}$ \\
\hline A5 & 0 & 0 & $\mathrm{P}$ & 0 & $\mathrm{P}$ & $\mathrm{P}$ \\
\hline A6 & $\geq 1$ & 0 & $\mathrm{~F}$ & 0 & $\mathrm{P}$ & $P$ \\
\hline A7 & $\overline{0}$ & 0 & $\mathrm{P}$ & 0 & $\mathrm{P}$ & $\mathrm{P}$ \\
\hline A8 & $\geq 1$ & 0 & $\mathrm{~F}$ & 0 & $\mathrm{P}$ & $\mathrm{P}$ \\
\hline A9 & $\overline{0}$ & 0 & $\mathrm{P}$ & 0 & $\mathrm{P}$ & $\mathrm{P}$ \\
\hline A10 & 0 & 0 & $\mathrm{P}$ & 0 & $\mathrm{P}$ & $\mathrm{P}$ \\
\hline A11 & $\geq 1$ & $\geq 1$ & $\mathrm{~F}$ & 0 & $\mathrm{P}$ & $\mathrm{P}$ \\
\hline A12 & $\sum 1$ & $\overline{0}$ & $\mathrm{~F}$ & 0 & $\mathrm{P}$ & $\mathrm{P}$ \\
\hline A13 & 0 & 0 & $\mathrm{P}$ & 0 & $\mathrm{P}$ & $\mathrm{P}$ \\
\hline A14 & 0 & 0 & $\mathrm{P}$ & 0 & P & P \\
\hline A15 & $\geq 1$ & 0 & F & 0 & $\mathrm{P}$ & $P$ \\
\hline A16 & 0 & 0 & $\mathrm{P}$ & 0 & $\mathrm{P}$ & $P$ \\
\hline A17 & $\geq 1$ & 0 & F & 0 & $\mathrm{P}$ & P \\
\hline A18 & $\overline{0}$ & 0 & $\mathrm{P}$ & 0 & $\mathrm{P}$ & $\mathrm{P}$ \\
\hline A19 & 0 & 0 & $\mathrm{P}$ & 0 & $\mathrm{P}$ & $\mathrm{P}$ \\
\hline A 20 & 0 & 0 & $P$ & + & $\mathrm{F}$ & $P$ \\
\hline A21 & 0 & 0 & $\mathrm{P}$ & 0 & $\mathrm{P}$ & $\mathrm{P}$ \\
\hline A22 & $\geq 1$ & $\geq 1$ & $\mathrm{~F}$ & 0 & $\mathrm{P}$ & $\mathrm{P}$ \\
\hline A23 & 0 & 0 & $\mathrm{P}$ & 0 & $\mathrm{P}$ & $\mathrm{P}$ \\
\hline A24 & $\geq 1$ & 0 & F & 0 & $\mathrm{P}$ & $\mathrm{P}$ \\
\hline A25 & $\geq 1$ & $\geq 1$ & F & 0 & $\mathrm{P}$ & P \\
\hline A26 & 0 & $\overline{0}$ & $\mathrm{P}$ & 0 & P & $\mathrm{P}$ \\
\hline A27 & $\geq 1$ & 0 & F & 0 & $\mathrm{P}$ & $\mathrm{P}$ \\
\hline A28 & $\geq 1$ & 0 & F & 0 & $\mathrm{P}$ & $P$ \\
\hline A29 & 0 & 0 & $\mathrm{P}$ & 0 & $\mathrm{P}$ & $P$ \\
\hline A30 & 0 & 0 & $\mathrm{P}$ & 0 & $\mathrm{P}$ & $\mathrm{P}$ \\
\hline A31 & $\geq 1$ & $\geq 1$ & F & 0 & $\mathrm{P}$ & $\mathrm{P}$ \\
\hline A32 & 0 & $\overline{0}$ & $P$ & 0 & $\mathrm{P}$ & P \\
\hline A33 & 0 & 0 & $\mathrm{P}$ & 0 & $\mathrm{P}$ & $\mathrm{P}$ \\
\hline
\end{tabular}

Bivariate analysis was done by using SPSS Statistics. There was no significant difference found between duration of operation since the establishment and both microbiological $(\mathrm{p}=0.956)$ and chemical $(\mathrm{p}=0.382)$ parameters. In terms of production capacity, it was also found that there were no differences in microbiological $(\mathrm{p}=0.384)$ and chemical $(\mathrm{p}=0.495)$ parameters. The result of the bivariate analysis was summarized in Table 3. 
Table 3. Summary of bivariate analysis

\begin{tabular}{|c|c|c|}
\hline Factors & Microbiological parameter (p-value) & Chemical Parameter (p-value) \\
\hline Duration of operation & 0.956 & 0.382 \\
\hline Production capacity & 0.384 & 0.495 \\
\hline
\end{tabular}

\section{DISCUSSION}

In this study, the authors aimed to assess the factors that influence the quality of refill drinking water, which consists of station management and raw water sources. There was a constant result found in factors related to DWRS managements (the number of office branches, type of ownership, certification) and the raw water source used. Therefore, those factors were omitted from the bivariate analysis.

Other factors, such as operating time and production capacity displayed varied results so that they could be analyzed by using SPSS. After being analyzed by using Chi-Square and Mann-Whitney test, the data show that there was no significant difference in the quality of refill drinking water related to the aforementioned factors.

In terms of water treatment, Kasim, et a ${ }^{(11)}$ in 2014 found that the use of disinfection and filter was not directly related to the quality of refill drinking water. It was thought to be confounded by other factors, such as the condition of machines, production capacity, and the quality of water sources. Navratinova, et $a l^{(12)}$ in 2019 found that some foctors concluded that sanitation and hygiene of DWRSs was a more important factor that influenced the quality of drinking water ${ }^{(12)}$ Therefore, further research that evaluates a wider range of factors is warranted.

This study also found that the duration since the establishment of refill drinking water did not have a significant relationship to the quality of refill drinking water. No matter how long DWRSs have operated that did not play a direct role with the refill drinking water quality because there was a requirement that had already been set by the local Health Department. As long as these requirements are met, the quality of refill drinking water from DWRSs would still meet the standard ${ }^{(13,14)}$.

There was another research conducted by Raksanagara, et $a l^{(15)}$ in 2018 about aspects that affect the quality of refill drinking water from DAMIU. The research was a qualitative study conducted by observation, in-depth interviews, and documentation review. The data obtained were then analyzed thematically. Based on this research, there were two factors that influence the quality of refill drinking water, namely internal and external factors. Internal factors included the human resource-related factors, namely the lack of knowledge, awareness, and behavior in DAMIU owners and workers. It later lowered the staffs' compliance in maintaining the quality standard of refill drinking water. The study also noted external factors that compromised the quality of refill drinking water, such as ineffectual government control, lack of sanctions, and lack of cooperation between government agencies ${ }^{(15)}$.

\section{CONCLUSION}

In conclusion, there are still many DWRS in Surabaya city can not pass the standart of quality refill drinking water. The data also showed that there were no significant differences found in relation with the station management (length of operation, production capacity, number of branches, type of business ownership, and certification) and source of raw water on the quality of refill drinking water.

\section{REFERENCES}

1. Kementerian Kesehatan Republik Indonesia. Regulation of the Minister of Health of the Republic of Indonesia number 492 about requirements for the quality of drinking water (Peraturan menteri kesehatan Republik Indonesia nomor 492 tentang persyaratan kualitas air minum). Jakarta: Kementerian Kesehatan Republik Indonesia; 2010.

2. Alegantina $\mathrm{S}$, Isnawati $\mathrm{A}$, Raini $\mathrm{M}$. Development of models for filtration and disinfection processes that affect the quality of refilled drinking water (Pengembangan model proses filtrasi dan disinfeksi yang mempengaruhi kualitas air minum isi ulang). Media Penelitian dan Pengembangan Kesehatan. 2018;18(3):144-50.

3. Ashbolt NJ. Microbial contamination of drinking water and disease outcomes in developing regions. Toxicology. 2004: 198 (1-3); 229-38.

4. Semba RD, de Pee S, Kraemer K, Sun K, Thorne-Lyman A, Moench-Pfanner R, Bloem MW, et al. Purchase of drinking water is associated with increased child morbidity and mortality among urban slum-dwelling families in Indonesia. International Journal of Hygiene and Environmental Health. 2009;212(4);387-97.

5. Jenning B, Duncan LL. Water safety and lead regulation: physicians' community health responsibilities. AMA Journal of Ethics. 2017;19:1027-35.

6. Calderon RL. The epidemiology of chemical contaminants of drinking water. Food and Chemical Toxicology. 2000; 38(1 Suppl); S13-S20.

7. Asyhadie Z. Business law: principles and practices in Indonesia (Hukum bisnis: prinsip dan pelaksanaannya di Indonesia). Jakarta: Raja Grafindo Persada; 2005.

8. Dinkes Kota Surabaya. Health profile of Surabaya (Profil kesehatan Surabaya) 2016. Surabaya: Dinkes Kota Surabaya; 2016.

9. Fick J, Söderström H, Lindberg RH, Phan C, Tysklind M, Larsson DG. Contamination of surface, ground, and drinking water from pharmaceutical production. Environmental Toxicology and Chemistry. 2009; 28: 2522-7.

10. International Organization for Standardization. ISO 9000 family - quality management. Geneva: ISO; 2015. 
11. Kasim KP, Onny SO and Endah NW. Factors associated with microbial contamination in drinking water refill on water station in Makassar city (Faktor-faktor yang berhubungan dengan cemaran mikroba dalam air minum isi ulang pada depot air minum kota Makassar). Jurnal Kesehatan Lingkungan Indonesia. 2014; 13: 39-44.

12. Navratinova S, Nurjazuli N, Tarwatjo T. Relationship of ultraviolet light disinfection with the bacteriological quality of refill drinking water in drinking water refill station (Hubungan desinfeksi sinar ultraviolet dengan kualitas bakteriologis air minum pada depot air minum isi ulang). Jurnal Kesehatan Masyarakat. 2019; 7: 412-20.

13. Kemenkes RI. Decree of the Minister of Health of the Republic of Indonesia number 907 about the requirements and supervision of the quality of drinking water (Keputusan Menteri Kesehatan Republik Indonesia No. 907 tentang syarat-syarat dan pengawasan kualitas air minum). Jakarta: Kementerian Kesehatan Republik Indonesia; 2002.

14. Kementerian Perindustrian dan Perdagangan Republik Indonesia. Decree of the Minister of Industry and Trade of the Republic of Indonesia Number 651 concerning the technical requirements for drinking water station and the Ministry of Trade and Industry (Keputusan menteri perindustrian dan perdagangan Republik Indonesia nomor 651 tentang persyaratan teknis depot air minum dan perdagangannya menteri perindustrian dan perdagangan). Jakarta: Kementerian Perindustrian dan Perdagangan Republik Indonesia; 2004.

15. Raksanagara AS, Fitriyah S, Afriandi I, Iskandar H, Sari SYI. Internal and external aspects of production quality of refill drinking water station: qualitative study in Bandung city (Aspek internal dan eksternal kualitas produksi depot air minum isi ulang: studi kualitatif di kota Bandung). Majalah Kedokteran Bandung. 2018;50:53-60. 